\title{
Withstanding the Goading of Temptation or Not? An inter-textual Study of Pride and Envy in Genesis Chapter 3: 1-19 and Shakespeare's Othello
}

\author{
David Torevell ${ }^{1}$ \\ ${ }^{1}$ Honorary Research Fellow, Leeds Trinity University, UK \\ Correspondence: David Torevell, Honorary Research Fellow, Leeds Trinity University, UK.
}

Received: July 29, 2019

doi:10.11114/ijsss.v7i6.4537
Accepted: September 2, 2019

Available online: September 24, 2019

URL: https://doi.org/10.11114/ijsss.v7i6.4537

\begin{abstract}
The tendencies towards pride and envy clearly continue to be key constituents of personal, political and social life, with inevitable harmful consequences. This article is an inter-textual examination of Genesis 3, 1-19 and Shakespeare's Othello and focusses on these two human failures. My aim is to illuminate how the Biblical Word might inform readings and performances of this tragedy and vice versa, in order to clarify the subtle and devastating nature of such leanings of arrogance. I start by discussing a central idea in Hannah Arendt's social philosophy: the move during modernity towards the exploration of the self, without a regard to any notion of a soul and then suggest this trajectory lends itself all too easily to amor sui (self-love), a theme St Augustine highlighted with such dexterity. I also argue that religion generally, and the Christian Church Fathers in particular, by their brilliant exegetical insights into the book of Genesis, identify remedies and a healing process for this dangerous narcissistic tendency, which are relevant today.
\end{abstract}

Keywords: religion, pride, envy, temptation, guilt, shame, (post)modernity

'Of man's first disobedience, and the fruit

Of that forbidden tree, whose mortal taste

Brought death into the world ...'

\section{Introduction}

(John Milton, Paradise Lost. Opening verse).

The thrust of this article is to clarify the constituency and dehumanisation of the deadly vices of envy and pride by an intertextual study of Genesis 3, 1-19 and Shakespeare's tragedy Othello. Four methods contextualise my discussion. First, by briefly alluding to Arendt's and other writings on one dominant trajectory in (post)modernity - the philosophical exploration of the self without any recourse to the existence of a soul or divine Being - I seek to articulate how the (post)modern age has become susceptible to envy and pride. Second, by summarising an argument about the nature of religion, I demonstrate how spiritual practices are concerned with and seek to combat failures such as pride and envy. Third, I mount a discussion of how the Christian Church Fathers, as wise biblical exegetes of the book of Genesis, gave insights into the aforementioned vices and offered skilful ways out of their entrapment. And fourth, I interweave throughout the text, extracts from Othello to further a deeper understanding of the two vices. Like Jesus on the road to Emmaus, I hope the Shakespearean text will open up further the meaning of the scriptural Word and conversely.

\section{2. (Post) Modernity's Disturbing Turn}

The American social theorist and philosopher Hannah Arendt (1906-1975) convincingly argues that much modern philosophy dangerously and exclusively concerns itself with the exploration of the self, ignoring any notion of the soul and by implication a divine Being $(1998,254)$. If there were to be any salvation for human existence during modernity, it seemed it had to emerge from humanity itself, and after Descartes, this entailed a strategy of intense doubting to arrive at some so-called secure base for knowledge. This inevitably led even to the doubting of the goodness of God Himself, (Dieu trompeur), a philosophical repetition of the striking occurrence in Genesis chapter three's account of the fall: "the woman whom you gave to be with me ...'(Gen 3: 12). During this time, therefore, the preferred 'solution' to the 
perplexities and ambiguities of the world was to move the Archimedean point to wo(man) her/himself (284). Arendt contends this was not really a solution at all, since 'inspired by a deep mistrust of the world ... it withdrew from worldly involvement into the security of an inward realm in which the self is exposed to nothing but itself' (309). Once the gaze was no longer fixed on God, it inevitably turned inwards to scrutinise the self for answers. Merton warned of this same tendency when he wrote about the wrong-headedness of the individualist whose 'interior life ... is precisely the kind of life that closes in on itself ... and rests in itself with more or less permanent satisfaction.' It 'resists the summons to communal witness and collective human response to God' $(2019,140)$. This must not be confused with Augustine's now famous discovery of God within his own heart when he asks in The Confessions: 'You are the strength of my soul; make your way in and shape it to yourself, that it may be yours to have and to hold, free from stain or wrinkle' (2012, 263; Torevell, 2007, 48-49). The modern turn inwards had nothing to do with the search for the divine.

For Arendt, this naturally led to an emphasis on the discovery of truth and knowledge fixed by action, productivity and scrutiny (symbolised by the invention of the telescope), all of which would move humanity's focus away from the contemplative and towards an insistent, self-willed determination of truth, primarily through science and technology. This is clearly witnessed today in the enterprise culture which has invaded education to an alarming degree (Furlong, 2013, 109-123). Earlier pre-modern, meditative approaches to the truth-offering 'given' of the universe, gave way to a neurotic, violent search for uncovering certainty, '... which forced the universe', in the words of Arendt, '....to yield its secrets' (my italics, 284). What ensued was a suspicion towards 'man's truth-receiving capacities' and a 'mistrust of the given' which had previously been the content and source of contemplation, whereby humanity found its home and resting place (298). What receded, contends Arendt, was the Heideggerian thaumazein, the shock of speechless wonder at the miracle of Being (302). It is a position McGilchrist endorses when he claims that the left hemisphere has dominated the right from the Enlightenment to the present day. He argues that Descartes epitomises this trajectory since his insistence on certainty led to 'a sense of being a passive observer of life, not an actor in it ...' $(2010,335)$ (and definitely not towards the belief in a created order), an attitude, he claims, which characterises the schizophrenic. For Marion, too, this mistrust of and separation from life, result in indifference to the world. The contrary experience of the 'givenness' of the world is characterised by amazement, stupor, bedazzlement, which alone allows the silent "voice" of Being to make itself heard' $(1995,117)$ and has to do 'with the fact that being is (given):' Arendt's 'mistrust' and McGilchrist's 'passive observer' become for Marion an experience of boredom, disengagement and withdrawal from 'everything, even everything, even and first from given being ...' (118). Consequently, '...nothing any longer makes a difference, including ontological difference' (118) as everyday life 'withdraws from being and from its stakes, as one withdraws from an affair ...' (118). This is another way of saying that the self took over from God and the created order as the definitive arena for the discovery of truth and once this occurred, the ego soon got a grip, enfolding pride and dominion into its clutches, replacing a humble and appreciative receptivity towards that which had been given. This was a disturbing turn which I now pursue with reference to its highlighting in Genesis chapter three and Shakespeare's Othello.

\section{The Nature of Religion}

I wish now to contextualise my argument further, by suggesting, along with Flood, that religion is partly about healing or repairing a broken humanity and restoring order to an otherwise collapsed world. In the Abrahamic faiths this is invariably associated with disobedience and sin, in Indic religions with ignorance and in Chinese religion with an imbalance or lack of harmony. Later I shall show repentance, humility and temperance are imperative to such healing in the Christian tradition and address directly the brokenness caused by pride and envy. Another way of describing this therapeutic nature of religion might be to say that they are attempts to 'resolve the tragic' and to bind back together that which has been wrenched apart through human fallibility (Flood, 2019, 2). Indeed, the etymological meaning of the Latin word religio, derived from ligo, to bind or connect, is probably from the prefixed re-ligare meaning to re-connect or fasten together again. In conjunction with this description of the nature of religion, Flood argues that spirituality is inextricably bound up with the desire for life at its deepest level and thus inevitably concerned with the consequences of its collapse when humanity becomes alienated from such a pursuit; religion, at its best, attempts to offer a means and context for the pursuit and revitalisation of life itself, experienced at its most profound and joyous levels. This human longing for life and its indelible association with the divine, is what religion is essentially about and it ensures and sustains an intensity and depth of living not found in other phenomena. This can occur on a personal, social or political level. As Freud contends, civilisations and religions' embeddedness within them, are often attempts to heal never-fulfilled and frustrated desire (Flood, 24). They have allowed human beings over time to seek and symbolise who they dream of becoming and to aspire to a life-filled vertical ascent away from the contingencies of dull existence; thus, they are both expressive and formative (Flood, 26). Religion offers the world a life overflowing with possibility, and, as Poole contends when discussing the nature of Greek and Shakespearean tragedy, is at the same time, profoundly concerned with the fall or gap from this life-enhancing potentiality. As he writes, 'The menace and promise of tragedy 
lie in this recognition of the sheer potentiality of all our selves we might be, and of all the worlds we might make together or destroy together' $(1988,2)$. There is thus a religious and spiritual overtone to Poole's definition. I shall discuss later how Adam and Eve become like fallen heroes in classical tragedy, alone (eremos) and abandoned.

In this quest for the fullness of life (John, 10,10), the 'ordinary' self is thus both transformed and healed by the touch of the transcendent. The longing of the self for 'real' life, is simultaneously a desire to leave that self which has become enmeshed in the deadening, mundane world, for without such a departure, it remains trapped within its own autonomous resources and tends towards narcissism, a condition, Lasch argues, driven by repressed rage and self-hatred (1979; Cook, 2019). Of course, this 'leaving;' might entail going further inside the self itself, in order to discover where the transcendent resides, as St. Augustine teaches in his Confessions (Torevell, 48-49), but it is nevertheless a departure from the inclination to become content with self-obsessing introspection and in this regard, as the Desert Christians have highlighted, it can be a painful process of transmutation, often entailing ascetical bouts of resilience against the earthly, flat and demonic (Evagrius of Pontus, 2006; Cassian, 1985).

\section{Pride and Envy}

In light of my previous contentions about the modern turn towards to the self, I now discuss one of the inclinations this trajectory encourages - pride and envy (Dyson, 2006; Epstein, 2003). I am using the word envy synonymously with the word jealousy used later with reference to Othello. Augustine tells us that since there was no prior evil in the garden, the door of pride let it in. Adam and Eve, succumbing to the false belief that they 'will be like God' $($ Gen 3,5$)$ gave in to their own pride, ironically falling away from God as a consequence. As the author of the book of Ecclesiasticus writes, 'Do not exalt yourself, or you may fall and bring dishonour upon yourself' $(1,30)$. Echoing my previous discussion of Arendt's description of the modern person, Augustine writes that they forsook the foundation on which the mind and heart were meant to rest, and instead opted for their own foundation $(1998,608 ; 2015)$. This is why he asks the pertinent question in his commentary in light of this prominence given to the self: "And what is pride but an appetite for a perverse kind of elevation?' (608). This kind of self-elevation, Anselm adds, is centred around the devil not only wanting to be equal to God - he even willed to be 'greater than God by desiring what God did not want him to, because he put his own will above God's' $(2008,203)$. Being far too well-pleased with himself, he 'willed what God did not want him to will, he inordinately willed to be like God' (202). The drift towards narcissism enters the world at this point and proceeds to embed itself over time at an alarming rate (Lasch). But as well as doing this, Adam refused to forsake his life's companion, Eve, and instead became 'her companion in sin' (Augustine, 608). Adam and Eve's partnership in crime thus came about because of the closeness of the bond between them and due to Adam not wishing to be separated from his only companion, even at the cost of sharing her misdoing. Augustine insists, ' $\ldots$ even though the woman committed the transgression because of the serpent's persuasion, and the man because of the woman's offer, the transgression was nonetheless their own act' (611).

This falling away from their true nature as children of God, did not entail, for Augustine, however, a complete loss of their being, but it certainly fractured a part of it and like Narcissus himself, it became diminished, losing the strength it previously had (609). Existing in oneself rather than in God, is tantamount to coming close to nothingness, as the heart raises itself up to itself, rather than to God. He comments that, 'By striving after more, man is diminished; when he takes delight in his own self-sufficiency, he falls away from the One who truly suffices him' (610). Ephrem the Syrian asks the pertinent question of them - did they become 'trapped in the imagined god-likeness that the serpent falsely promised?' (Louth, 2001, 84). What became clear was that Christ did the reverse of what Adam and Eve did, when He refused to cling on (Griffiths, 2018, 60-78) to His equality with God and submitted Himself to the level of a slave (Phil 2,1-11).

Paradoxically, Augustine tells us, it is humility which elevates and exalts the mind, for it ascends by making itself subject to God. There is something about exaltation to God which abases the mind, unlike the devil's exaltation of himself, which held a proud sway over him. Throughout the City of God Augustine teaches his readers that love is the central dynamic when it comes to practising Christianity. The problem can never be love itself, but to what chosen object it is directed. He reassures that the right object of love is God and humanity (one's neighbour), made in the image of God. Other objects are merely idols. St. Paul in his letter to the Philippians. denounces the same tendency: 'Their god is the belly; and their glory is in their shame; their minds are set on earthly things' $(3,19)$. And he encourages his readers to stand firm in the Lord ...' (4, 1 my italics). Augustine claims that 'in the one city of God, love of God has been given pride of place, and, in the other, love of self (amor sui)' (609; O'Donovan, 2006). He advises that Adam and Eve had already become too pleased with themselves before the devil's temptation and that is why Adam was susceptible to and delighted with the claim that they will become like God. It connected to a proud, psychological state and mindset to which he was already moving. Clearly, Adam and Eve would have been better aligned to becoming gods (after-all they were made in the image and likeness of God), if they had 'clung to the highest and true ground of their being and not, in their pride, made themselves their own ground' (610). By proudly striving for more than what had 
been donated, they became diminished. Augustine uses the metaphor of light to describe this descent into self-love Adam is delighted with himself as if he were his own light and thus turned away from that Light "which, if only he had been pleased with It instead, would have made the man himself a light' (610).

As I suggested earlier, disobedience is an essential part of Abrahamic faiths' understanding of downfall and disintegration and they are concerned with healing this collapse. Obedience, for Augustine, is the mother and father of all virtues. Humanity has been so made that it is to their advantage to be subject to God and it is harmful to act according to its own will, rather than that of their Creator. In the garden, because desire was not in opposition to the will, the unrighteousness of disobeying the command was all the greater in proportion to the ease with which it could be avoided. Augustine encourages his readers to realise that pride and envy were the overwhelming factors associated with disobedience in the devil's fall. The proud fallen angel, envious by reason of that same pride which had induced him to turn away from God encouraged Adam to gloat over subjects of his own, rather than be subject to God himself.

The serpent does the same with all those whom he wishes to deceive. He similarly 'sought to insinuate himself, by crafty suggestion, into the heart of man, whose unfallen state he envied now that he himself had fallen' (606, my italics). The devil chose to speak 'through this creature 'slippery and moving in twisted coils' (606). Iago similarly creeps upon Othello with astute deviousness, making the audience shudder. He decides 'to abuse Othello's aer' (Act 1, 3, 1371) and, like the devil, by using intelligent, underhand suggestions, he penetrates the core of Othello's being: 'there where I have garnered up my heart/Where either I must live or bear no life' (Act 4, 2. 156-57). Of course, this creature of stealth, who was in fact the devil, was not what it seemed, for it had assumed a disguise to deceive Adam and Eve who fell victim to its duplicity. Iago, too, just like the devil, is never what he seems. This reverberating theme throughout the play is heightened by the repeated dramatic irony of several lines which reinforce this truth: Iago's 'Men should be what they seem' is echoed by Othello's reply, 'Certain, men should be what they seem' (Act 3, 3,128-9).

Because of these despicable means, when the devil is found out, he will be forced, says Ambrose, to crawl on his belly, a fitting punishment since he is a creature of pleasure and will be made to 'eat of what is earthly and who, weighed down with food', shall be 'bent over toward what is of earth' (Louth, 89).There persists throughout the play a clever, verbal manipulation of those who will eventually fall. Emilia is well suited to her husband Iago, in this regard, since both are skilled and pragmatic rhetoricians who pay attention to the intricacies of argumentation and syllogism (Bevington, 2008,163). Iago's line about the inevitability of Desdemona's infidelity due to her husband's age - 'She must change for youth; when she is sated with his body, she will find the error of her choice' (Act 1, 31339 ), is a rhetorical piece of philosophical logic based on a premise, even if it is a seductively false one. As Bevington observes, Iago is 'the most audacious and compelling thinker in the play' (162).

John Cassian, in his Conference 18 explores this notion of the envy of the good person. One of the brethren, like the brothers of Joseph, was 'filled with the wish to sully the other man's beauty, with some tarnish or stain' (1985, 196-198). He claimed that the devout Abba Paphnutius had stolen his book from his cell, but in reality, he had planted it there as evidence of his guilt. Paphnutius, although innocent, agreed to do penance for his assumed wrong-doing. Finally, the culprit, 'the sly purloiner of another's good name', admitted his guilt and confessed his sin to Paphnutius, 'whose reputation he had in jealous hostility sought to take away'; he received pardon from the Abba and was freed from his guilt (197). Paphnutius is held up by this moral action, as one who was mature in faith and to be followed as an exemplar. Augustine reminds his readers that the pride of the transgressor Adam was greater than the transgression itself. When he tried to excuse himself by blaming Eve '...she gave me of the tree. ... Nowhere here is there heard any petition for pardon, nor indeed, any plea for healing' (611). This situation is no better when it comes to Eve herself: 'The woman's pride blames the serpent, the man's pride blames the woman' (611). And 'where there was so manifest a transgression of the divine command, this was more of an accusation than an excuse' (611), for 'nothing is to be believed or obeyed in preference to God's command' (611). Although Coleridge famously suggested that Iago acts out of motiveless motivation, for me the reason is clear - envy. Some productions seek to illuminate this by suggesting Iago's envy of Othello's promotion to a great warrior and leader; others infer that he is envious of Othello making love to the person he lusts after, Desdemona, and in some performances, when Iago is portrayed as a gay man, he is shown as being fiercely envious of Desdemona who shares her bed with the person with whom he wishes to sleep .

For the Biblical commentator, Richardson, the serpent should be seen not as something external to our nature, but as a personification of temptation $(1963,71)$. Like Iago's suggestion to Othello that Desdemona might not be as good as she appears to be - 'She did deceive her father, marrying you' (Act 1, 3,1209), the serpent appeals to the vanity of Adam and Eve, insinuating doubts about the virtuous nature of God Himself. He writes that disobedience and doubting are two parallel processes, quoting Kierkegaard's maxim 'It is hard to believe because it is hard to obey' (72). Once we emancipate ourselves from God's law, we desire to assert ourselves. He sums up what he believes is the great teaching of Genesis chapter three - 'the fatal weakness of human nature is man's desire to give glory to himself and not the Creator ... Pride is the root and essence of all human sinfulness...'. He ends: 'God bids us to worship Him not ourselves '(72). 


\section{Shame and the Inability to Stand}

The consequences of succumbing to pride and envy are clarified in the Biblical narrative. At the moment Adam and Eve were stripped of grace through their disobedience, they felt shame about their own nakedness, a self-conscious erosion of their being they did not feel earlier before their fall. Their prior nakedness before God and each other was not a thing of which to be ashamed. Heart-felt lovers do not feel embarrassed by seeing their own and the other's naked flesh together. In fact, they forgot they were naked at all, for they rejoiced in their createdness and their love for each other, in a natural, unconscious manner. It is only when lovers become estranged by selfishness, pride and envy, that they begin to feel awkward and embarrassed at the sight of each other (and of God), with whom previously they had felt no such thing. Notice how Masaccio's painting of the banishment The Expulsion (1424-1428) painted for the church of the Carmelite nuns in Florence, situates Adam and Eve as lonely, separate bodies, unable to look each other in the face, whereas previously they were able to look deeply into each other's eyes, without a flicker of self-consciousness. Once they realized they had sinned and disobeyed God, Adam and Eve, in shame, start to hide from God, from each other and from themselves, since they could no longer face and stand up to the truth of their self-willed alienation from God. Greenblatt writes that 'The prime source of their misery no doubt is the shame and guilt they feel as a result of their transgression ...' but he is also right to emphasize how the image of Eve, attempting to cover her genitals with one hand, her breasts with another, suggests 'a primordial sense of what she must do in face of an unendurable exposure' (2018, 149). Although referring more generally to the notion of shame in Levinas' ethics, Dalton makes an important point about the consequences of this feeling which is relevant to my argument: 'When shamed the subject's natural response is to flee, to cover itself, to find shelter from the exposing gaze of the Other, like Adam in the garden' (128). He goes on: 'Accused by the Other, the subject finds itself reduced to an object with which it cannot immediately identify. ... Forced to confront itself from another perspective, the I falters in the face of its own being. It cannot stand the presentation of itself offered in the accusation of the other experienced in shame' (Dalton, 2009, 129-130, my italics). Roderigo, unlike the villainous Iago, feels shame even at the thought of being infatuated with Desdemona. He declares 'It is my shame to be so fond, but it is not in my virtue to amend it' (Act 1,3,1311-2).

Clearly, as in this case, shame can work to the good, if one does not hide from the truth and one is able to face openly one's own wrong-doing. A too great a pleasing with oneself leads to a displeasure with oneself and to feelings of shame, since it elevates (wo)man to a position contrary to their nature. Augustine reminds us that feeling shame after doing wrong is not a bad thing at all for it can lead to repentance and the rediscovery of God: 'The Holy psalm also says this: 'Fill their faces with shame; that they may seek Thy name, O Lord' (610). Adam and Eve, like Peter in another garden, Gethsemane, could not withstand the pressure of their temptation and fell asleep. For the former, it was over briefly with one bite of the apple, for Peter, it was over in a day, first on the Mount of Olives where he could not stay awake to pray 'that you may not come into the time of trial' (Luke, 22, 46) and when later that night he denied his Master three times, as the cock crowed, 'he went outside and wept bitterly' (Luke 22, 62). But Peter's character, according to Augustine, was 'more wholesome when he wept than when he was pleased with himself and presumptuous' (610). As was Othello's when he wept as he confronted his wife with his accusation of adultery and in his wife's bedchamber before he murdered her: 'I must weep' (Act 4, 2, 1 41; Act 5, 2, 1 20). Indeed, towards the end of the play, we hear Othello, out of shameful hatred for himself, condemn himself and offer himself up for punishment: - 'O cursed, cursed slave! Whip me, ye devils/From the possession of this heavenly sight! Blow me about in winds! Roast me in sulphur!' (Act 5, 2, 1275-77). There is a repentant awareness of his need to be punished for his crime. But his anguish at his own failings overrides any redemptive move towards self-forgiving or a forgiving God; consequently, he stabs himself in despair. Conversely, Iago is completely devoid of shame because, like Julian Kaye, he no longer believes in love.

The self-imposed punishment of Adam and Eve is described as an experience of the brutalised earth rather than of heaven. All vertical ascent has been lost and the horizontal becomes all too real and deeply unsettling. Adam and Eve can no longer stand erect in the presence of God. Their banishment means they will have to endure the earth as cursed under their feet (Zornberg, 1995, 21). They are no longer on solid ground and cannot stand before God in prayer any longer. Midrashic sources, referred to by Zornberg, describe how on the sixth day of creation God stood humanity on its legs (21) and they looked like ones 'made in the image of God (psalm 93, 1), with divine majesty and strength. But sin has made them incapable of standing. As in the Greek myth of Narcissus, they begin to lose strength and to dissolve in the reflection of their own self-love.

Their insecure posture cannot hold for long, so they fall. Before their disobedience, Adam could 'hear God speaking and stand on his legs ... he could withstand it', writes Zornberg. After the fall, 'he shrinks and pretends, like Hamlet, not to be' (23). His real existence once substantiated in relation to his Creator God, fades away and he loses all stability and balance as he moves out of the garden. There is for Adam now a 'spinelessness, a vapidity, A splendid being decomposes before our eyes' (24). Othello suffers a similar fate of collapse, physically, emotionally, spiritually, when he is unable to withstand the pressure of the relentless, subtle goading of Iago and his formidable but warped intellect. Like 
Adam he ends up a lonely figure, isolated from everyone and everything. Before the fall, Adam and Eve's adoration of God along with the animals, signified a common bond between all created beings in relation to their Creator. This was no longer possible after their sin; they started to wander restlessly and aimlessly, bereft of all relationships and social support. Their previously firm vantage point (Arendt's Archimedean) from where they could see both the heavens and the earth, caved in.

Augustine in De Trinitate advises further on the constituency of Adam and Eve's fall. It resulted in a privatised life, cut off from social groupings: 'The soul slipped away from the shared whole to its own restricted part' (quoted in O'Donovan, 2006, 101-102). The two entered the world outside the garden, lonely and isolated, even from each other. They were unable to stand up straight and were bent double, because they failed to heed the liturgical encouragement to lift up their hearts (sursum corda) to the Lord and instead sought their own ascension through pride. The resultant space of the private was not only a diminished sphere, but an unstable one since it became founded on materialism. St Paul (2. Tim 3,2) draws our attention to this inevitable fate - once people become lovers of themselves, they become lovers of money also. Iago's words on money echo this descent as he insistently tells Roderigo to 'Put money in your purse' (Act $1,3,1330$ ) to secure Desdemona's hand.

\section{Ways Forward}

St. John Chrysostom comments that a person's hiding from God is a result of abandoning Him and starting to love what is his alone (Louth 81). This hiding is all the more acute because God offers his gentle voice of welcoming return 'at the time of the evening breeze' when all is 'still and calm' $($ Gen 3, 8). Of what is there to be afraid one might ask? Besides, it is impossible to hide from God who asks the terrifyingly rhetorical question Adam and Eve do not wish to hear: 'Where are you?' (Gen 3, 9). Symeon comments that God searches for Adam because he loves him and 'God was not angered, nor did he immediately turn away. Rather, he gave him the opportunity for a second reply and said, Who told you that you were naked?' (85-6), but the latter flees from Him because he is ashamed of the person he has become. All that is required is for Adam and Eve to no longer hide and to repent, thereby renewing openly their relationship with God. Any attempted hiding is bound to be redundant. Of this behaviour Symeon writes, 'Do you think you can hide from me?' (Louth, 86), implying that all they need to do is to say sorry and then they will no longer feel the need to hide. The banishment and suffering which occur are therefore self-imposed, not brought about by God at all. It is simply the natural consequence of not obeying God's commands and then refusing to admit a wrong has been committed suffering naturally ensues.

The Desert Father, Evagrius of Pontus (c. 345-399), in discussing his understanding of 'thoughts' (logismoi) which arise in the mind and heart in spiritual battles, tells us that some are deeply susceptible to temptation (2006, 30; Torevell, 2010). What is required to combat these is the strength to nobly bear dishonour when we are afflicted by them (30-1). It is also necessary to 'shut in the beast of irascibility' when someone attacks you and wishes to take vengeance on you (32). But if one succumbs to temptation and exaggerated self-esteem, you become 'the slave of a barbarian mistress' and 'sold to many masters - pride, jealousy, envy ...'(31). If only Othello had taken this advice to heart things would have been very different. Speaking of the vice of unguarded self-esteem, Evagrius sums up both Othello's and Iago's failing well, pointing to the dangers of clinging to a sense of misplaced honour, the progenitor of pride which in turn leads to hatred: 'He who wishes to be honoured envies the one who surpasses him in fame and by his jealousy he piles up hatred towards his neighbours;' (31); Indeed, Othello tells Roderigo that he has told him often 'and I re-tell thee again and again, I hate Moor' (Act 1, 3, 1366-7). It seems, too, that Othello grows to hate his wife, wishing the 'whore' had 'ne'er been born!' (Act 4, 2, 168); such vitriol is borne out of a deep sense of sexual envy he feels towards his rival. Milton modelled his portrait of Satan in Paradise Lost partly on Iago's cunning hatred. Konyndyk DeYoung endorses this point when she suggests that hatred is a vice that arises from envy which includes the dimension of self-hating leading to self-destruction (2009, 43). Envy of someone else's superiority makes you feel your own lack, your own inferiority, more acutely. Aquinas, too, advises that there is a progression in envy, using the word 'detraction' to demonstrate how it leads to practical deeds of vengeance, involving deceitful and underhand strategies to release its venom. The zenith occurs when due to your own engineering, the envious person rejoices at the cruel downfall (schadenfreude) of their victim (46). The envious person, Konyndyk argues, is also characterised by 'passive -aggressive stabs in the back and invariably shuns open warfare, since 'to come out in the open and declare one's envy is to admit and display one's inferiority' (47). This is particularly true of Iago who admits that his 'it is my nature's plague /To spy into abuses, and oft my jealousy/ Shapes faults that are not' (Act 3, 3, 1147-9). Aquinas adds that 'We envy only those whom we wish to rival or surpass in reputation' (quoted in Kondyndyk DeYoung, 49). Indeed, Othello is acutely aware of the robbing of his own reputation due to the alleged adultery of Desdemona: 'But he that filches from me my good name/Robs me of that which not enriches him/And makes me poor indeed' (Act 3, 3, 1160-163). Towards the end of the play Othello admits that his murderous act has resulted in his wish to die which, like Hamlet's famous soliloquy 'To be or not to be' appears to offer some small crumb of comfort, a desperate release from his 
anguished state of mind and his corrupted heart; he declares: 'For in my sense, 'tis happiness to die' (5.2. 287). In his increasing state of confusion and envy, Othello cannot articulate with any sense, the real cause of his vengeful murder for his beloved wife: 'It is the cause, it is the cause, my soul: /Let me not name it to you, you chaste stars/It is the cause' (Act $5,2,11$ ) he despairingly fumbles. He is unable to name exactly what the motive is for his fury, just as in the earlier scene when Desdemona asks how she has wronged him he replies frustratingly, 'Ah, Desdemona, away, away, away!' (Act 4, 2, 140). The director might choose here to dramatize how Desdemona clings to her husband in disbelief as he pushes her away, so that he is able to become disentangled from her, or Othello might gesture to imply that they should get away from this pointless talk. Whichever, Othello displays an angry mind and an inability to give sound reasons for his fury; he is on the verge of mental derangement due to jealousy, even after Iago has warned him not to fall victim to it sinister proceedings since it is '.. the green-eyed monster which doth mock/The meat it feeds on' (Act 3, $31168-9$ ). Othello's reply to Iago when he pledges that he will never let this vice overtake his life: 'Why - why is this?/Think'st thou I'd make a life of jealousy/To follow still the changes of the moon/With fresh suspicion?' (Act 3.3.1179-181) turns out to be one of the most lethal ironies in the play.

The way out of this trap of envy, advises Evagrius, is through humility which combats 'the entire legion of the demons (cf. Mark 5: 9);'(31) and is the virtue of which the demons are particularly afraid, being one of the 'garments of the Lord' (52). He closes in on this vice when he writes, 'the disguise of Satan ... in the person of the serpent blamed the Most High in order to attribute his own jealousy of God by pretending it came from the mouth of another' (44). He adds that the 'demons are jealous of those who are dazzling bright in their submission to a (spiritual) father' (53). And with reference to shame, he contends that the thoughts surrounding this lodge in the heart once 'they have gained a foothold to converse with the soul' (39). Therefore, he who does not persevere in stillness 'brings warfare to his soul ... but the person who loves stillness guards the senses and makes war on thoughts' (40). For Ambrose the antidote to such pride and avarice is temperance (Louth, 77). This is echoed in Diadochus's claim that the senses without moderation distract the heart from remembrance of God (Louth, 78).

John Chrysostom suggests that lust, a sibling of pride and envy, is a consequence of the soul no longer being subject to God (Louth, 81). Iago asks Othello to imagine his wife 'naked with her friend in bed' (Act 4, 1,13) and since he does not believe in love, with racial contempt, he likens their marital relationship to lustful bestiality: 'even now, now, very now, an old black ram/Is tupping your white ewe' (Act 1, 1, 1 88-89; Smith, 2019, 212-213). This is echoed in Hamlet's rage to his mother when he imagines her making love to his murderous uncle living 'In the rank sweat of an enseamed bed/Stewed in corruption, honeying and making love/Over the nasty sty -' (Act 3, 4, 1 89=92). Envy thus attributes false and base motives to others, especially in the area of sexual jealousy. Honigmann puts forward the view that imagining others having sex can be as titillating as or perhaps more disturbing than actually witnessing the act (Shakespeare, 2016, 44). Certainly, the inter-relationship between envy, lust and hatred becomes evident as the dramas of Genesis and Othello unfold. Adam and Eve became lustfully entrapped by the sensual beauty of the apple due to their own avarice suggests Ephrem the Syrian; they were tempted by their own desire: 'Even if the tempter had not come, the tree itself, by its beauty, would have caused them a great struggle due to their avarice' (Louth 77). Temperance is the answer to such desire, writes Ambrose (Louth, 77). But a thorough treatment of this theme of lust is for another article (Blackburn, 2006).

The great twentieth century Christian writer, Henri Nouwen, offers further reflections on humility in light of Genesis chapter three. He contrasts the Desert Fathers and Mothers with Adam and Eve. The former did not hide from their Creator, but instead ventured out into the open spaces of a wild landscape where they could face head on their own failings and ask repentance for their shortcomings $(1981,67)$. Their prayer lives encouraged them to see God not as an enemy, but as a friend who would assist them to mend their broken lives. Such prayer 'requires the humble recognition of our own condition as broken human beings. However, prayer does not lead us to shame, guilt or despair we are only human' (67) And besides, hiding is illusory and counter-productive since 'we are hiding behind a hedge through which everyone can see' (68). Here again we witness the antidotes to the shame brought about through disobedience, pride and envy - repentance and humility - which eradicate the need to hide and which secure God's merciful grace in times of trouble.

\section{Concluding Remarks}

What I have attempted to do in this article is to clarify how the twin vices of pride and envy are the foundation of Adam and Eve's fall and Othello's and Iago's too. The subtle deviousness of the devil (and Iago) was able to penetrate their susceptibility to these inclinations and because they were unable to eradicate the shame they felt after their fall, they suffered devastating self-imposed consequences. The later remedies offered by the Church Fathers in their penetrating exegetical examination of Genesis chapter three, were clearly not in the minds and hearts of Adam, Eve, Othello or Iago. It is not surprising, therefore, that tragedy ensued. It remains to be seen whether such failings will become even more prominent in our present (post)modern culture. 


\section{References}

Anselm of Canterbury. (2008). The Major Works. Davies, B. and Evans G.R. (eds.), Oxford: Oxford University Press.

Arendt, H. (1998). The Human Condition. Chicago: The University of Chicago Press. https://doi.org/10.7208/chicago/9780226924571.001.0001

Augustine. (1998). Augustine. The City of God against the Pagans. Dyson, R. W. (ed.). Cambridge: Cambridge University Press.

Augustine. (2012). The Confessions. Meconi, D. V. (ed.). Boulding, M. (trans.). San Francisco: Ignatius Press.

Augustine. (2015). Essential Expositions of the Psalms. Hyde Park, New York, NY: New City Press of the Focolare.

Bevington, D. (2008). Shakespeare's Ideas. More Things in Heaven and Earth. Oxford: Wiley-Blackwell.

Blackburn, S. (2006) Lust. Oxford: Oxford University Press.

Cassian, J. (1985). Conferences. New York, NY: Paulist Press.

Cook, B. (2013). Pursuing Eudaimonia. Re-appropriating the Greek Philosophical Foundations of the Christian Apophatic Tradition. Newcastle: Cambridge Scholars Press.

Dalton, D. M. (2009). Longing for the Other. Levinas and Metaphysical Desire. Pittsburgh, Pennsylvania: Duquesne University Press.

Dyson, M. E. (2006). Pride. Oxford: Oxford University Press.

Epstein, J. (2003). Envy. Oxford: Oxford University Press.

Evagrius of Pontus. (2006). Evagrius of Pontus. The Greek Ascetic Corpus. Sinkewicz, R. (trans.). Oxford: Oxford University Press.

Flood, G. (2019). Religion and the Philosophy of Life. Oxford: Oxford University Press. https://doi.org/10.1093/oso/9780198836124.001.0001

Furlong, J. (2013). Education - An Anatomy of the Discipline. Rescuing the university project? London: Routledge. https://doi.org/10.4324/9780203078853

Greenblatt, S. (2018). The Rise and Fall of Adam and Eve. The Story that Created Us. London: Vintage.

Griffiths, P. (2018). Christian Flesh. Stanford, California: Stanford University Press.

Honigmann, E. (ed.). (2016). Shakespeare, William. Othello. London: Bloomsbury Arden Shakespeare.

Konyndyk DeYoung, R. (2009). Glittering Vices. A New Look at the Seven Deadly Sins and their Remedies. Ada MI 49301: Brazos Press.

Louth, A. (ed.). (2001). Genesis 1-11. Ancient Christian Commentary on Scripture. Old Testament 1. Downers Grove, Illinois 60515: InterVarsity Press.

Marion, J. L. (1995). God Without Being. Chicago: The University of Chicago Press.

McGilchrist, I. (2010). The Master and his Emissary. The Divided Brain and the Making of the Western World. Yale: Yale University Press.

Merton, T. (2019). Where Prayer Flourishes. Canterbury: Canterbury Press.

Milton, J. (2005). Paradise Lost. Oxford: Oxford University Press.

Nouwen, H. (1981). The Way of the Heart. Desert Spirituality and Contemporary Ministry. San Francisco: HarperSanFrancisco.

O’Donovan, O. (2006). The Problem of Self-Love in St. Augustine. Eugene, Oregan: Wipf and Stock Publishers.

Poole, A. (1988) Tragedy. Shakespeare and the Greek Example. Oxford: Basil Blackwell.

Richardson, A. (1963). Genesis 1-11. London: SCM Press.

Schimmel, S. (1997). The Seven Deadly Sins. Jewish, Christian and Classical Reflections on Human Psychology. Oxford: Oxford University Press.

Thompson, A., \& Taylor, N. (eds.). (2018). Shakespeare, William. Hamlet. London: Bloomsbury Arden Shakespeare.

Smith, E. (2019). This is Shakespeare. London: Pelican.

Torevell, D. (2007). Liturgy and the Beauty of the Unknown. Another Place. Aldershot: Ashgate. 
Torevell, D. (2010). 'Like a Jar of Wine Left in its Place for a While ...Clear, Settled and Perfumed ...' Evagrius of Pontus and the Purifying Engagement of Stillness. In J. Schmack, M. Thompson \& D. Torevell, with C. Cole (Eds.), Engaging Religious Education. (pp 171-184). Newcastle: Cambridge Scholars Publishing.

Zornberg, A. G. (1995). The Beginning of Desire. Reflections on Genesis.New York, NY: Schocken Books DVD. American Gigolo (1980, Schrader, P).

\section{Endnotes}

${ }^{\mathrm{i}}$ The iconic painting of this kind of proud self-love is represented vividly in Poussin's seventeenth century Echo and Narcissus (1625-1630). Narcissus dissolves and loses strength as he looks intently, with eyes only for himself, into the water to see his own image reflected back upon himself. Echo, his girlfriend, looks on in dismay, but in the hope he will eventually see the error of his ways and look upon her instead. Cupid observes the scene, too, the ever-present flame of true love burning, which has been temporarily extinguished by the self-love of Narcissus. Poussin's landscape suggests that Echo's hope might not be realised and that Narcissus will be doomed forever to his self-inflicted fate. The definitive film portrayal of proud narcissism is well represented in American Gigolo (Schrader, 1980). The handsome, shirtless, bronzed-toned Julian Kaye, played by Richard Gere, erotically dresses as a high-priced male escort, in preparation for his evening seductive rendezvous, by selecting a shirt and tie from a raft of options and stands in front of the mirror to adore his own sexualised image, while high on cocaine. In Augustine's terms, he was far too pleased with himself. Smokey Robinson and the Miracles' track The Love I saw in You is just a Mirage plays during the ritual, suggesting a dangerous self-delusion about the whole thing. Although the film contrasts and endorses true love with sexual pleasure to some degree, the impact of the movie was far from instructive about the dangers of pride and self-love. Kaye, unlike Adam and Eve, feels no shame when he reveals his own nakedness to his client and to the audience. Without any feeling of love and the regret of its abandonment, shame and a sense of guilt are bound to be absent. Many viewers fell for the illusion that such unashamed self-elevation is a thing to be admired; Armani clothes sales went through the roof and lots of men wished to look and be like Gere. The following u-tube responses to the scene are typical of many: 'I saw this as a little boy. I vowed to live the gigolo life. 25 years later I'm still living the gigolo DREAM' and from another 'I watch this video before every interview I go to'.

\section{Copyrights}

Copyright for this article is retained by the author(s), with first publication rights granted to the journal.

This is an open-access article distributed under the terms and conditions of the Creative Commons Attribution license which permits unrestricted use, distribution, and reproduction in any medium, provided the original work is properly cited. 